\title{
Aplikasi Teori Planned Behavior di SMAK dan SMTI Sebagai Implementasi Kebijakan Lingkungan Kementerian Perindustrian
}

\author{
Agus Siswono $^{2 *}$, Lailan Syaufina ${ }^{2}$, Siti Badriyah. Rushayati ${ }^{3}$ \\ ${ }^{1}$ Program Studi Ilmu Pengelolaan Sumberdaya Alam dan Lingkungan, Sekolah Pascasarjana, \\ Institut Pertanian Bogor, Bogor 16680, Indonesia \\ 2 Departemen Silvikultur, Fakultas Kehutanan, Institut Pertanian Bogor, Kampus IPB Dramaga, \\ Bogor 16680, Indonesia \\ ${ }^{3}$ Departemen Konservasi Sumberdaya Hutan dan Ekowisata, Fakultas Kehutanan, Institut \\ Pertanian Bogor, Kampus IPB Dramaga, Bogor 16680, Indonesia
}

*Email: lasikaroro@yahoo.com

\begin{abstract}
ABSTRAK
Kementerian Perindustrian sangat konsen dengan masalah lingkungan dapat dilihat dari kebijakan pengembangan industri yang ramah lingkungan (industri hijau). Salah satu program reposisi kementerian untuk unit sekolah adalah penataan lingkungan sekolah menjadi green school. Penelitian ini bertujuan menganalisis tingkat pengetahuan, sikap, dan intensi perilaku peduli lingkungan siswa SMK Kemenperin, menganalisis hubungan pengetahuan lingkungan hidup, sikap, norma subjektif dan persepsi kontrol perilaku terhadap intensi perilaku peduli terhadap lingkungan siswa SMK Kemenperin, dianalisis dengan menggunakan program excell dan Struktural Partial Least Square (PLS). Hasil analisis menunjukkan pengetahuan lingkungan hidup, sikap dan intensi perilaku peduli lingkungan siswa SMK Kemenperin sangat baik oleh responden. Hasil analisis uji dengan Struktural Partial Least Square (PLS) diketahui bahwa variabel pengetahuan lingkungan hidup berpengaruh positif terhadap sikap tetapi tidak signifikan, sementara sikap, norma subjektif dan persepsi kontrol perilaku berhubungan positif dan berpengaruh signifikan terhadap intensi perilaku peduli lingkungan siswa SMK Kemenperin.

Kata kunci: green school, intensi perilaku, Partial Least Square (PLS), persepsi kontrol perilaku, sikap

\section{PERNYATAAN KUNCI}

Kebijakan lingkungan Kementerian Perindustrian di dunia industri dengan program industri hijau, di internal kementerian diterapkan program $5 \mathrm{~K}$ (Keteraturan, Kerapihan, Kebersihan,

Kelestarian, Kedisiplinan), dalam unit pendidikan sekolah SMAK dan SMTI didorong menjadi sekolah adiwiyata dan Green School atau sekolah hijau adalah sekolah yang memiliki komitmen dalam mengembangkan program-program untuk
\end{abstract}


menginternalisasikan nilai-nilai lingkungan ke dalam seluruh aktivitas sekolah (Paryadi, 2008 dalam Komisi Nasional Indonesia untuk UNESCO, 2015).

Program sekolah Adiwiyata dan green school tujuannya mewujudkan siswa mempunyai pengetahuan, sikap dan berperilaku peduli terhadap lingkungan. Pengetahuan lingkungan yang bagus akan mampu membentuk sikap peduli lingkungan yang bagus pula, sikap peduli lingkungan yang baik akan membentuk perilaku peduli lingkungan yang baik pula. Menurut Lee (2011) Pengetahuan lingkungan yang baik akan berdampak pula pada sikap perilaku manusia yang baik pula. Kepedulian lingkungan mengacu pada tingkat keterlibatan emosional individu dalam isu-isu lingkungan yang merupakan respon afektif individu terhadap perlindungan lingkungan.

\section{REKOMENDASI KEBIJAKAN}

Kementerian Perindustrian harus mendorong sekolah menengah kejuruan (SMAK dan SMTI) untuk ikut program Adiwiyata nasional. Sekolah yang sudah mendapatkan penghargaan Adiwiyata Nasional didorong menjadi program Adiwiyata mandiri dan menjadi sekolah green school.

Kementerian Perindustrian harus mendorong sekolah menengah kejuruan (SMAK dan SMTI) menjadi sekolah Adiwiyata Green School Indonesia (AGSI) merupakan perpaduan antara Green School dan program Adiwiyata dimana proses implementasi telah diintegrasikan dengan kurikulum nasional. Sekolah AGSI adalah sekolah yang mampu mengoptimalkan potensi sumber daya alam sebagai solusi pemecahan permasalahan yang dihadapi, memiliki komitmen untuk mengembangkan program dengan menginternalisasikan nilainilai lingkungan ke dalam seluruh aktifitas sekolah.

\section{PENDAHULUAN}

Pemerintah dewasa ini membuka kran investasi yang luas untuk meningkatkan pembangunan dan pertumbuhan ekonomi. Investasi di bidang industri sangat diharapkan karena investasi di bidang industri dapat membawa multiplier effect bagi perekonomian nasional seperti peningkatan pada nilai tambah bahan baku dalam negeri, penyerapan tenaga kerja, dan penerimaan devisa. Meningkatnya jumlah industri akan banyak menggunakan sumber daya alam, tanpa adanya keselarasan dapat mengakibatkan kerusakan lingkungan, untuk itu diperlukan pembangunan industri dengan konsep pembangunan yang berkelanjutan atau sustainable development. Penerapan konsep industri hijau bertujuan mendorong berbagai perusahaan untuk terus meningkatkan efisiensi dan efektivitas produksi melalui penghematan biaya dan sumber daya alam. 
Undang-Undang Republik Indonesia No. 3 Tahun 2014, tentang Perindustrian Industri Hijau adalah industri yang dalam proses produksinya mengutamakan upaya efisiensi dan efektivitas penggunaan sumber daya secara berkelanjutan sehingga mampu menyelaraskan pembangunan Industri dengan kelestarian fungsi lingkungan hidup serta dapat memberikan manfaat bagi masyarakat. Tahun 2014 sampai saat ini, sudah dicapai konsensus atas SIH untuk 17 jenis industri, yaitu industri semen portland, ubin keramik, pulp dan kertas, susu bubuk, pupuk buatan tunggal hara makro primer, pengasapan karet, karet remah, serta tekstil pencelupan, pencapan dan penyempurnaan, gula kristal putih, kaca pengaman berlapis, kaca pengaman diperkeras, barang lainnya dari kaca, kaca lembaran, penyamakan kulit, pengawetan kulit, baja flat product, dan baja long product. Beberapa peraturan yang dikeluarkan Kementerian Perindustrian berkaitan dengan industri hijau (Kemenperin, 2019):

- Peraturan Menteri Perindustrian No 26 Tahun 2018, Standar Industri Hijau Untuk Industri Semen Portland.

- Peraturan Menteri Perindustrian No 27 Tahun 2018, Standar Industri Hijau Untuk Industri Pupuk Urea, Pupuk SP36, dan Pupuk Amonium Sulfat.

- Peraturan Menteri Perindustrian No 28 Tahun 2018, Standar Industri Hijau
Untuk Industri Pengolahan Susu Bubuk.

- Peraturan Menteri Perindustrian No 39 Tahun 2019, Standar Industri Hijau untuk Industri Batik.

- Peraturan Menteri Perindustrian No 40 Tahun 2019, Standar Industri Hijau untuk Industri Kertas Budaya.

- Peraturan Menteri Perindustrian No 41 Tahun 2019, Standar Industri Hijau untuk Minyak Goreng dari Kelapa Sawit.

Menurut Dwiwahjono (2019) industri hijau sudah menjadi tuntutan seiring semakin tingginya kepedulian pasar akan kelestarian lingkungan dan pembangunan yang berkelanjutan. Secara umum Industri Hijau memiliki karakteristik antara lain menggunakan bahan kimia yang ramah lingkungan, menerapkan reduce, recycle, reuse dan recovery pada proses produksi, menggunakan intensitas energi yang rendah, menggunakan intensitas air yang rendah, menggunakan SDM yang kompeten, melakukan minimisasi limbah dan, menggunakan teknologi rendah karbon. (Widyasari, 2013).

Pengembangan dan pembinaan perusahaan menjadi Industri Hijau oleh Kementerian Perindustrian diperlukan sumber daya manusia kompeten dan sadar terhadap lingkungan. Pembangunan SDM internal Kementerian Perindustrian yang kompeten dan berwawasan lingkungan 
sangat penting seperti yang tertuang dalam Reposisi Pengembangan Unit Pendidikan dan Balai Diklat Industri. Pusdiklat Industri Kementerian Industri, diantaranya tugas dari sekolah SMAK dan SMTI menyediakan SDM yang kompeten berwawasan lingkungan sehingga meningkatkan produktivitas dan berdaya saing di dunia industri. Mendorong SMAK dan SMTI menjadi sekolah kejuruan industri bertaraf internasional dan sepenuhnya berbasis spesialisasi, kompetensi dan sekolah hijau (green school) melalui kurikulum yang terinternalisasi pendidikan lingkungan hidup.

Pendidikan Lingkungan Hidup (PLH) adalah suatu program pendidikan untuk membina anak atau peserta didik agar memiliki pengertian, kesadaran, sikap, dan perilaku yang rasional serta bertanggung jawab sebagai tentang pengaruh timbal balik antara penduduk dengan lingkungan hidup dalam berbagai aspek kehidupan manusia (Pratomo. dalam Afandi, 2013).

Menurut Undang-Undang Nomor 32 Tahun 2009 tentang Perlindungan dan Pengelolaan Lingkungan Hidup. Dalam undang-undang tersebut dinyatakan bahwa setiap orang berhak untuk berperan dalam perlindungan dan pengelolaan lingkungan hidup. Sehingga diatur bagaimana setiap orang berperan dalam perlindungan dan pengelolaan lingkungan hidup dan diwajibkan untuk memelihara kelestarian fungsi lingkungan hidup, serta mengendalikan pencemaran dan/atau kerusakan lingkungan hidup.

Kementerian Negara Lingkungan Hidup (KNLH) pada tanggal 19 Februari 2004 bersama-sama dengan Departemen Pendidikan Nasional, Departemen Agama dan Departemen Dalam Negeri telah menetapkan Kebijakan Pendidikan Lingkungan Hidup (PLH). Tanggal 21 Februari 2006 telah dicanangkan Program Adiwiyata, yaitu sekolah peduli dan berbudaya lingkungan. Program Adiwiyata dicanangkan untuk mendorong dan membentuk sekolah-sekolah di Indonesia agar dapat turut melaksanakan upaya-upaya pemerintah menuju pelestarian lingkungan dan pembangunan berkelanjutan bagi kepentingan generasi sekarang maupun yang akan datang.

Terdapat 4 komponen yang harus diperhatikan sekolah untuk dikelola dengan baik dalam menjalankan Adiwiyata yang meliputi kebijakan sekolah berwawasan lingkungan, kurikulum berbasis lingkungan, kegiatan lingkungan berbasis partisipatif, dan sarana dan prasarana pendukung ramah lingkungan. Melalui program-program lingkungan disekolah-sekolah seperti adiwiyata, green school, Tim Adiwiyata Nasional KLHK (2013).

Penelitian ini bertujuan untuk menganalisis tingkat pengetahuan, sikap, dan intensi perilaku peduli lingkungan siswa SMK Kemenperin (SMAK dan SMTI). Menganalisis hubungan pengetahuan lingkungan hidup, sikap, norma subjektif 
dan persepsi kontrol perilaku terhadap intensi perilaku peduli terhadap lingkungan siswa SMK Kemenperin (SMAK dan SMTI).

\section{SITUASI TERKINI}

Menteri perindustrian telah mengeluarkan Peraturan Menteri Perindustrian No 23/M-IND/PER/2/ 2009 tentang Penerapan Keteraturan, Kerapihan, Kebersihan, Kelestarian, Kedisiplinan $(5 \mathrm{~K})$ di Lingkungan Departemen Perindustrian, diperkuat Keputusan menteri Perindustrian Nomor 491/M-IND/Kep/8/2016 Tanggal 24 Agustus 2016 tentang pedoman pengembangan sekolah menengah kejuruan industri berbasis kompetensi yang link dan match dalam industri, sebagaimana tertuang dalam program reposisi tahap dua pusdiklat industri, SMK-SMTI Kemenperin menjadi role model pendidikan Kejuruan Industri berbasis kompetensi yang menghasilkan tenaga kerja industri yang kompeten dan berdaya saing.

Kementerian Perindustrian sedang melakukan penataan lingkungan sekolah (SMK dan SMTI) menjadi Green School, sekolah memperoleh sertifikat ISO 14000 , terbebas dari rokok.

Sekolah Menengah Kejuruan (SMAK dan SMTI) banyak yang belum menjadi sekolah Adiwiyata, tidak ada satupun sekolah sudah Adiwiyata mandiri. Sekolah Menengah Kejuruan (SMAK dan SMTI) belum ada yang menerapkan green school, apalagi AGSI.
Pembangunan gedung sekolah, ruang kelas belum mengacu pada green school seperti ventilasi ruang kelas yang baik untuk mengurangi penggunaan $\mathrm{AC}$, mengurangi jumlah ruang ber AC dan kelas ber AC.

Taman yang masih sedikit, pembelajaran di luar kelas seperti di taman, di lapangan masih belum maksimal, program-program lingkungan masih minim di sekolah (SMAK dan SMTI).

Kepedulian lingkungan siswa SMK (SMAK dan SMTI) masih relatif rendah, hal ini dapat dilihat dari sering meninggalkan sampah di selasar, ruang kelas dan locker meja mereka. Siswa SMK (SMAK dan SMTI) masih belum mampu memilah jenis sampah dalam membuang sampah.

\section{METODOLOGI}

Penelitian ini merupakan penelitian deskriptif dan eksplanasi. Penelitian deskriptif adalah penelitian yang menggambarkan perilaku, pemikiran, atau perasaan suatu kelompok atau individu.

Alat dan bahan yang digunakan dalam penelitian ini berupa lembar tes pengetahuan lingkungan hidup, kuisioner untuk responden. Lembar tes pengetahuan dinilai skor betul 1, skor salah 0. Lembar kuisioner menggunakan skala pengukuran likert 5 point. Alat yang digunakan berupa kamera untuk dokumentasi objek penelitian dan software Smart PLS2.

Populasi dalam penelitian ini adalah siswa SMK Kemenperin meliputi SMKSMAK Bogor dan SMK SMTI Yogyakarta Sampel 32 siswa dari SMK-SMAK Bogor 
dan 59 siswa dari SMK- SMTI Yogyakarta meliputi kelas kompetensi keahlian kimia analisis dan kimia indutri. Pengambilan sampel dilakukan secara purposif sampling yaitu kelas XI, yang sudah cukup mendapatkan materi praktik K3, lingkungan penanganan limbah. Kegiatan penelitian ini dilaksanakan dalam jangka waktu 7 bulan, terhitung mulai Bulan Januari 2019 sampai dengan Juli 2019

Analisis data dengan MS Excel 2016 untuk mengetahui tingkat pengetahuan lingkungan, sikap dan perilaku peduli lingkungan siswa SMK Kemenperin, menganalisis hubungan antar variabel dengan menggunakan analisis Struktural Partial Least Square (PLS). PLS adalah suatu teknik statistik multivariat yang bisa untuk menangani banyak variabel respon serta variabel eksplanatori sekaligus
Variabel endogen dalam penelitian ini adalah sikap dan Intensi perilaku peduli lingkungan. Variabel eksogen adalah pengetahuan lingkungan hidup, norma subyektif, dan persepsi kontrol perilaku siswa sekolah SMK Kemenperin dengan model penelitian disajikan pada Gambar 1. Variabel endogen, eksogen beserta indikatornya selengkapnya dapat dilihat pada Tabel 1.

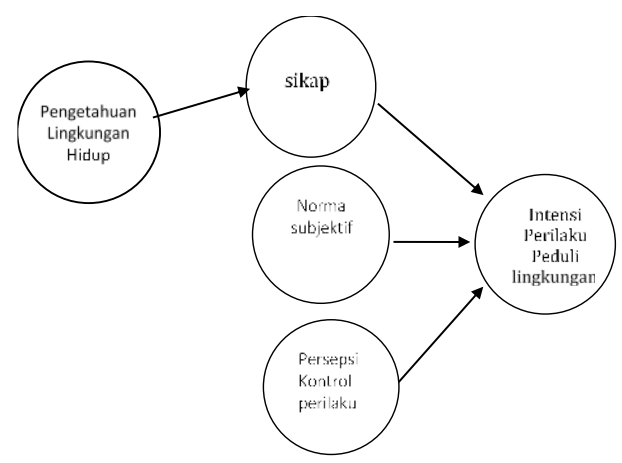

Gambar 1. Kerangka Model Penelitan 
Tabel 1. Variabel endogen dan variabel eksogen model struktural partial least square (PLS)

\begin{tabular}{|c|c|c|c|}
\hline \multirow{16}{*}{$\frac{\text { No }}{1}$} & Variabel & Indikator & Ket \\
\hline & $\begin{array}{l}\text { Variabel } \\
\text { Eksogen }\end{array}$ & $\begin{array}{l}\text { Pengetahuan siswa tentang pencemaran dan sumber sumber } \\
\text { pencemaran }\end{array}$ & PLH1 \\
\hline & & pengetahuan siswa tentang dampak kerusakan lingkungan & PLH2 \\
\hline & Pengetahuan & Pengetahuan siswa tentang pencegahan dan kerusakan lingkungan & PLH3 \\
\hline & Lingkungan & $\begin{array}{l}\text { Pengetahuan Siswa tentang pengelolaan lingkungan dan } 5 \mathrm{R} \text { ( reduce, } \\
\text { reuse, recycle, replace dan replan) }\end{array}$ & PLH4 \\
\hline & Norma & Orang tua & NS1 \\
\hline & Subjektif & Guru & NS2 \\
\hline & & Teman & NS3 \\
\hline & Persepsi & Sarana tempat sampah yang cukup dan terbagi sampah organik dan & PKP1 \\
\hline & Kontrol & non organik & PKP2 \\
\hline & Perilaku & Alat kebersihan tersedia dan memadai & \\
\hline & & Memiliki taman. dan tanaman di sekolah maupun di rumah & PKP3 \\
\hline & & Memiliki lampu hemat enrgi dan fasilitas air yang bagus. & PKP4 \\
\hline & & Memiliki tempat minum dan makan yang ramah lingkungan. & PKP5 \\
\hline & & Memiliki barang hasil daur ulang & PKP6 \\
\hline & & Memiliki alat sarana transportasi ramah lingkungan. & PKP7 \\
\hline \multirow[t]{13}{*}{2} & \multirow{2}{*}{$\begin{array}{l}\text { Variabel } \\
\text { endogen }\end{array}$} & Sampah dibuang pada tempat dan sesuai kriteria & S1 \\
\hline & & Partisipasi dalam kebersihan lingkungan & $\mathrm{S} 2$ \\
\hline & Sikap Peduli & Senang pada aktivitas merawat dan menanam pohon. & S3 \\
\hline & \multirow[t]{4}{*}{ Lingkungan } & Menghemat Pemakaian energi listrik dan air & S4 \\
\hline & & Senang menggunakan produk-produk ramah lingkungan & S5 \\
\hline & & $\begin{array}{l}\text { Senang mendaur ulang kertas, botol plastik menjadi produk baru } \\
\text { yang bermanfaat }\end{array}$ & S6 \\
\hline & & Memilih menggunakan transportasi umum dalam bepergian & S7 \\
\hline & Intensi & Membuang sampah pada tempatnya & IPPL1 \\
\hline & \multicolumn{3}{|l|}{ Perilaku } \\
\hline & Peduli & Membersihkan lingkungan sekitar & IPPL2 \\
\hline & \multirow[t]{3}{*}{ Lingkungan } & Merawat tanaman dan menanam pohon & IPPL3 \\
\hline & & Menghemat pemakaian energi dan air & IPPL4 \\
\hline & & Menggunakan produk-produk ramah lingkungan. & IPPL5 \\
\hline
\end{tabular}

Keterangan: PKP7. dihilangkan dari konstruk karena memiliki outer louding $<0,5$ atau tidak valid dan reliabilitas.

\section{ANALISIS DAN \\ ALTERNATIF SOLUSI}

\section{Karakteristik Responden}

Responden dalam penelitian ini adalah siswa SMK Kemenperin yang ada di Bogor dan Yogyakarta. Total reponden yang dikumpulkan oleh peneliti adalah sebanyak 91 siswa, 32 siswa dari SMK Kemenperin Bogor (SMK-SMAK Bogor) dan 59 siswa dari SMK Kemenperin Yogyakarta (SMK- SMTI Yogyakarta). Gambaran umum responden selanjutnya berdasarkan kompetensi keahlian, jenis kelamin, usia dan ekstrakurikuler yang diikuti. Karakteristik demografi responden dapat dilihat pada Tabel 2. 
Tabel. 2. Karakteristik demografi responden.

\begin{tabular}{llll}
\hline Karakteristik & Ketegori & Jumlah & Persen (\%) \\
\hline \multirow{3}{*}{ SMK Kemenperin } & SMK-SMAK Bogor & 32 & 35.16 \\
Kompetensi keahlian & SMK-SMTI Yogyakarta & 59 & 64.84 \\
& Kimia analisis & 62 & 68.13 \\
jenis kelamin & Kimia industri & 29 & 31.87 \\
& laki-laki & 48 & 52.75 \\
Usia & perempuan & 43 & 47.25 \\
& 15 & 2 & 2.20 \\
& 16 & 61 & 67.03 \\
& 17 & 26 & 28.57 \\
& 18 & 1 & 1.10 \\
& 19 & 1 & 1.10 \\
\hline
\end{tabular}

Sumber: Diolah dari data primer dengan MS Excel 2016

Responden menurut jenis kelamin siswa laki-laki sebanyak 52.75\%, siswa perempuan sebanyak $47.25 \%$. Menurut usia responden didominasi siswa berusia 16 tahun sebanyak $67.03 \%$, berusia 17 tahun sebanyak $28.57 \%$, berusia 15 tahun $2.20 \%$, usia 18 tahun $1.10 \%$ dan usia 19 tahun $1.10 \%$.

\section{Hasil Analisis Deskriptif Variabel}

Hasil analisis deskriptif dapat dilihat pada Tabel 3. Berdasarkan Tabel 3 dapat digambarkan bahwa keseluruhan indikator dimensi pengetahuan lingkungan hidup dipersepsikan sangat baik oleh responden dengan nilai rata-rata skor sebesar 4.49. Pengetahuan mereka terhadap pencegahan pencemaran dan kerusakan lingkungan memiliki nilai rata-rata skor tertinggi yaitu sebesar 4.57. Pengetahuan responden tentang $5 \mathrm{R}$ (reduce, reuse, recycle, replace dan replant) memiliki nilai rata-rata skor terendah yaitu sebesar 4.33. Pengetahuan siswa mengenai $5 \mathrm{R}$ perlu ditingkatkan dengan melalui pendidikan dan ketrampilan penanganan sampah, pemanfaatan sampah, menanam pohon, taman hijau yang dimasukkan dalam program ekstrakurikuler IPA/lingkungan 
Tabel 3. Hasil analisis deskriptif

\begin{tabular}{llll}
\hline Variabel & $\begin{array}{l}\text { Rata-rata } \\
\text { skor }\end{array}$ & Kategori & Keterangan \\
\hline $\begin{array}{l}\text { Pengetahuan } \\
\text { Lingkungan Hidup }\end{array}$ & 4.49 & $\begin{array}{l}\text { Sangat } \\
\text { Baik }\end{array}$ & $\begin{array}{l}\text { Pengetahuan lingkungan hidup siswa SMK } \\
\text { Kemenperin sangat baik terutama tentang } \\
\text { pencemaran pencegahan kerusakan lingkungan. }\end{array}$ \\
\hline $\begin{array}{l}\text { Sikap Peduli } \\
\text { Lingkungan }\end{array}$ & 4.32 & $\begin{array}{l}\text { Sangat } \\
\text { baik }\end{array}$ & $\begin{array}{l}\text { Sikap peduli lingkungan siswa SMK } \\
\text { Kemenperin sangat baik dalam hal sampah } \\
\text { harus dibuang pada tempat dan sesuai } \\
\text { kriterianya. }\end{array}$ \\
\hline Norma Subjektif & 4.07 & Sangat & $\begin{array}{l}\text { Norma subyektif siswa SMK Kemenperin } \\
\text { tergolong sangat baik, mereka patuh saran, } \\
\text { pendapat orangtuanya. }\end{array}$ \\
\hline $\begin{array}{l}\text { Persepsi Kontrol } \\
\text { Perilaku }\end{array}$ & 3.79 & Baik & $\begin{array}{l}\text { Persepsi kontrol perilaku siswa SMK } \\
\text { Kemenperin baik dalam hal tersedianya sarana } \\
\text { tempat sampah yang cukup dan terbagi sampah } \\
\text { organik dan non organik }\end{array}$ \\
\hline $\begin{array}{l}\text { Intensi Perilaku } \\
\text { Peduli Lingkungan }\end{array}$ & 4.33 & Sangat & $\begin{array}{l}\text { Intensi perilaku peduli lingkungan siswa SMK } \\
\text { Kemenperin sangat baik dalam hal membuang } \\
\text { sampah pada tempatnya dan sesuai kritesia }\end{array}$ \\
\hline
\end{tabular}

\begin{abstract}
Penilaian responden terhadap seluruh indikator sikap peduli lingkungan mendapat penilaian yang sangat baik dari responden. Rata-rata jawaban responden terhadap variabel sikap lingkungan adalah 4.32. Rata-rata skor jawaban responden yang tertinggi yaitu sebesar 4.55 adalah pada sikap sampah harus selalu dibuang pada tempatnya dan sesuai kriteria sampah. Rata-rata skor jawaban terendah dari responden sebesar 3.95 yaitu pada sikap memilih menggunakan transportasi umum dalam bepergian.
\end{abstract}

Sumber: Diolah dari data primer dengan MS Excel 2016

Solusi alternatif untuk meningkatkan sikap siswa dalam hal transportasi, membuat kebijakan pembatasan siswa menggunakan sepeda motor dan mendorong siswa dan warga sekolah mengunakan transportasi umum atau transportasi yang ramah lingkungan seperti sepeda, motor listrik.

$$
\text { Penilaian responden terhadap }
$$
seluruh indikator norma subyektif dipersepsikan sangat baik oleh responden. Hal ini dapat dilihat dari rata-rata jawaban responden pada indikator norma subyektif adalah 4.07. Saran dan pendapat dari orang tua untuk berperilaku peduli lingkungan memiliki rata-rata skor tertinggi yaitu 4.22. Rata-rata skor terendah adalah pada pernyataan responden tentang saran dari teman atau sahabat untuk berperilaku peduli lingkungan dengan nilai rata-rata skor 3.78. Hal ini menunjukkan peran guru dalam pembentukan perilaku peduli lingkungan siswa di SMK Kemenperin 
(SMAK dan SMTI) masih kurang maksimal. Solusi alternatif meningkatkan peran guru. Peran guru adalah untuk mengatur, mengarahkan, memandu, membantu dan mendukung dalam aktifitas kognitif murid (Kostova dan Atasoy, 2008).

.Persepsi kontrol perilaku adalah ketersediaan sumberdaya berupa peralatan seperti tempat sampah, kompatibelitas, kompetensi, dan kesempatan (control belief strength) yang mendukung atau menghambat perilaku yang akan diprediksi dan besarnya peran sumber daya tersebut (power of control factor) dalam mewujudkan perilaku tersebut. Keseluruhan dari indikator persepsi kontrol perilaku dipersepsikan baik oleh responden. Ratarata skor jawaban responden pada variabel persepsi kontrol perilaku sebesar 3.79 atau termasuk baik. Rata-rata skor tertinggi sebesar 4.25 pada pernyataan bahwa Tersedianya sarana tempat sampah yang cukup dan terbagi sampah organik dan non organik sudah sangat baik di sekolah SMK (SMAK dan SMTI), sedangkan ratarata skor terendah sebesar 3.52 pada pernyataan memiliki barang hasil daur ulang, artinya siswa memandang disekolah belum banyak pendidikan dan pelatihan daur ulang limbah menjadi suatu produk. Solusi alternatif dalam penelitian ini sarana dan prasarana perlu dtingkatkan dalam pengolahan limbah, bank sampah, pemanfaatan limbah, daur ulang sampah dan limbah, seperti pemanfaatan botol minuman kemasan untuk tanaman hidroponik.

Penilaian responden terhadap indicator intensi perilaku peduli lingkungan mendapat penilaian yang sangat baik dari responden. Rata-rata jawaban responden pada variabel intensi perilaku peduli lingkungan adalah 4.33 .

Rata-rata skor tertinggi sebesar 4.64 dari pernyataan responden pada intensi perilaku membuang sampah pada tempatnya dan sesuai kriteria. Rata-rata skor terendah sebesar 4.03 dari pernyataan responden pada intensi perilaku merawat tanaman dan menanam pohon.

Alternatif solusi masih rendahnya intensi perilaku merawat tanaman dan menanam pohon, memberikan teladan dan memberikan proses pembelajaran yang mengintegrasikan aspek pembangunan berkelanjutan atau lingkungan kedalam seluruh tema dilaksanakan melalui pendekatan saintifik seperti praktik menanam pohon, baik disisipkan dalam kurikulum maupun di praktikkan dalam kegiatan ekstrakurikuler. Melibatkan siswa dalam pembuatan taman sekolah, siswa berperan dalam menanam sayur secara, menanam buah di lingkungan sekolah. 


\section{Hasil Uji Partial Least Square}

Hasil pengukuran validitas dan reliabilitas dari seluruh variabel dengan mengukur convergent validity dan composite reliability, discriminant validity, indikator refleksif dapat dilihat pada Tabel 4. Nilai dari cross loading antara indikator dengan konstruknya. cross loading pada model pengukuran ini telah memenuhi persyaratan validitas diskriminan. Nilai AVE baik untuk variabel pengetahuan lingkungan hidup, norma subyektif, persepsi kontrol perilaku, sikap peduli lingkungan, dan intensi perilaku peduli lingkungan menunjukkan angka lebih besar dari 0.50 . indikator pada kontruk persepsi kontrol perilaku (PKP7) dihilangkan karena memiliki outer loading dibawah 0.50. Menurut Chin (1998) dalam
Ghozali (2012), suatu kolerasi dapat dikatakan memenuhi validitas konvergen apabila memiliki nilai outer loading lebih besar dari 0.5 .

Pengukuran composite reliability, seluruh konstruk dalam model pengukuran dinyatakan reliabel karena nilai composite reliability dan cronbach alpha baik untuk variabel pengetahuan lingkungan hidup, norma subyektif, persepsi kontrol perilaku, sikap peduli lingkungan dan intensi perilaku peduli lingkungan adalah diatas 0.70. Menurut Sarwono dan Narimawati (2015) menyatakan bahwa suatu variabel laten dapat dikatakan mempunyai realibilitas yang baik apabila nilai composite reliability lebih besar dari 0.7 dan nilai cronbach alpha lebih besar dari 0.7 .

Tabel 4. hasil pengukuran variabel

\begin{tabular}{lrrrrr}
\hline Notasi & Outer Loading & t-value & $\begin{array}{r}\text { Composite } \\
\text { Reliability }\end{array}$ & $\begin{array}{r}\text { Cronbah's } \\
\text { Alpha }\end{array}$ & AVE \\
\hline PLH1 & 0,895 & 1,209 & 0,883 & 0,823 & 0,655 \\
PLH2 & 0,672 & 0,821 & & & \\
PLH3 & 0,819 & 1,114 & & & \\
PLH4 & 0,835 & 1,942 & & & 0,682 \\
\hline S1 & 0,752 & 5,642 & 0,937 & 0,921 & \\
S2 & 0,889 & 8,968 & & & \\
S3 & 0,843 & 6,079 & & & \\
S4 & 0,878 & 8,659 & & & \\
S5 & 0,926 & 7,493 & & & \\
S6 & 0,777 & 6,818 & & & \\
S7 & 0,691 & 5,848 & & & \\
\hline NS1 & 0,880 & 8,700 & 0,901 & 0,835 & \\
NS2 & 0,894 & 11,056 & & & \\
NS3 & 0,827 & 8,001 & & & \\
\hline PKP1 & 0,704 & 4,322 & 0,889 & 0,851 & \\
PKP2 & 0,711 & 4,299 & & & \\
PKP3 & 0,854 & 5,969 & & &
\end{tabular}




\begin{tabular}{lrrrrl} 
PKP4 & 0,662 & 3,727 & & & \\
PKP5 & 0,777 & 5,358 & & & \\
PKP6 & 0,825 & 7,722 & & & \\
\hline IPPL1 & 0,638 & 5,205 & 0,846 & 0,774 & 0,526 \\
IPPL2 & 0,663 & 4,947 & & & \\
IPPL3 & 0,791 & 10,304 & & \\
IPPL4 & 0,788 & 9,258 & & \\
IPPL5 & 0,732 & 8,702 & & \\
\hline
\end{tabular}

Sumber : Diolah dari data primer dengan Smart PLS2

\section{Model Struktural (Inner Model)}

Pemeriksaan model struktural meliputi signifikansi hubungan jalur dan nilai $\mathrm{R}$ Square $\left(\mathrm{R}^{2}\right)$ untuk melihat hasil evaluasi model struktural, khususnya signifikansi dari variable moderating. Nilai $R^{2}$ bertujuan untuk mengetahui seberapa besar variabel independen mempengaruhi variabel dependennya. Nilai $R^{2}$ dapat dilihat pada Tabel 5.

Tabel 5. Nilai R Square

\begin{tabular}{lc}
\hline & R Square \\
\hline Intensi Perilaku Peduli & 0.471 \\
Lingkungan & \\
Norma Subjektif & \\
Pengetahuan Lingkungan & \\
Hidup & \\
Persepsi Kontrol Perilaku & \\
Sikap Peduli Lingkungan & 0.0312 \\
\hline
\end{tabular}

Sumber: Diolah dari data primer dengan Smart PLS2

Nilai R Square intensi perilaku lingkungan sebesar 0.4709 berarti variabilitas variabel intensi perilaku peduli Tabel 6. Nilai path coefficient (mean, STDEV, t-values) lingkungan dapat dijelaskan oleh variabel persepsi kontrol perilaku, norma subjektif, dan sikap peduli lingkungan interaksinya sebesar $\quad 47.09 \%$, sedangkan $52.91 \%$ dijelaskan oleh variabel lain yang tidak terdapat dalam penelitian ini.

Nilai R Square sikap peduli lingkungan sebesar 0.0312 berarti variabilitas variabel sikap peduli lingkungan dapat dijelaskan oleh variabel pengetahuan lingkungan hidup interaksinya sebesar $3.12 \%$, sedangkan $96,88 \%$ dijelaskan oleh variabel lain yang tidak terdapat dalam penelitian ini

Hasil bootstrapping dari analisis PLS2 dapat dilihat pada Tabel 6. Berdasarkan Tabel 6 dapat dijelaskan analisis hubungan antar variabel. 


\begin{tabular}{lllll}
\hline & $\begin{array}{c}\text { Orginal } \\
\text { Sampel (O) }\end{array}$ & $\begin{array}{c}\text { Sample } \\
\text { Mean (M) }\end{array}$ & $\begin{array}{c}\text { Standard } \\
\text { Deviation } \\
\text { (STDEV) }\end{array}$ & t Statistic \\
\hline $\begin{array}{l}\text { Pengetahuan Lingkungan Hidup }>\text { Sikap } \\
\text { Peduli Lingkungan }\end{array}$ & 0.1766 & 0.1921 & 0.1418 & 1.2457 \\
$\begin{array}{l}\text { Sikap Peduli Lingkungan }>\text { Intensi Perilaku } \\
\text { Lingkungan }\end{array}$ & 0.3561 & 0.3802 & 0.1086 & 3.2784 \\
$\begin{array}{l}\text { Norma Subjektif }>\text { Intensi Perilaku Peduli } \\
\begin{array}{l}\text { Lingkungan. } \\
\text { Persepsi Kontrol Perilaku }>\text { Intensi Perilaku }\end{array}\end{array}$ & 0.2364 & 0.2245 & 0.1173 & 2.0156 \\
\hline \begin{tabular}{l} 
Peduli Lingkungan \\
\hline
\end{tabular} & & 0.3151 & 0.0865 & 3.5245 \\
\hline
\end{tabular}

Sumber: Diolah dari data primer dengan Smart PLS2

Hasil analisis model struktural pengujian hubungan antar variabel dengan
Partial Least Square menggunakan softhware smartPLS2 dapat dilihat pada Gambar 2.

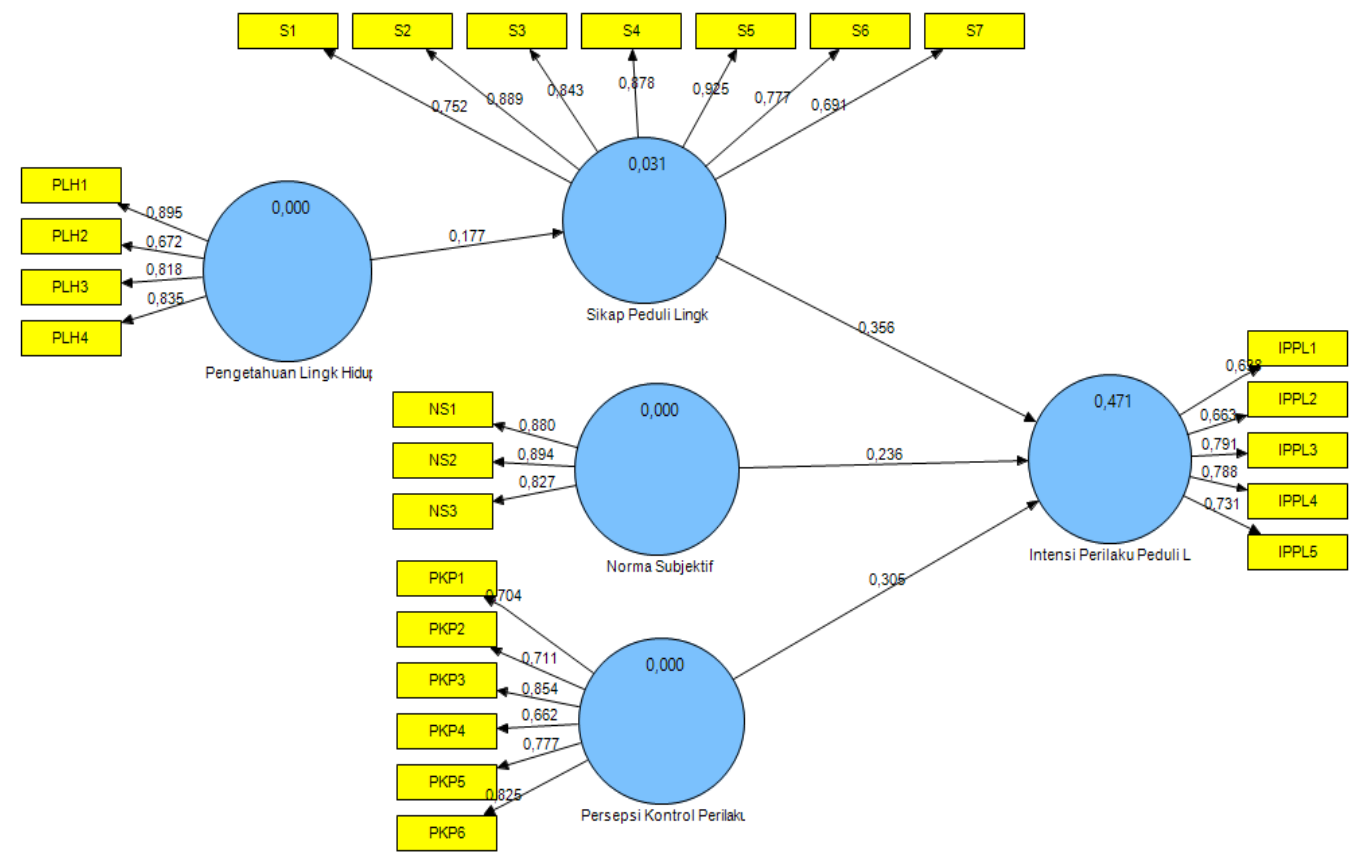

Gambar.2 Model pengukuran hasil uji PLS menggunakan software SmartPLS 2. 
Analisis hubungan antara

Pengetahuan Lingkungan Hidup terhadap Sikap Peduli Lingkungan.

Hasil analisis menggunakan

SmartPLS 2 menujukkan hasil bahwa hubungan variabel pengetahuan lingkungan hidup dengan sikap peduli lingkungan sebesar 0.177, yang berarti pengetahuan lingkungan hidup berpengaruh secara positif terhadap sikap peduli lingkungan tetapi tidak signifikan karena nilai t statistik hitung $1.24<\mathrm{t}$ Tabel 1.988 seperti pada Tabel 6. Hal ini menunjukkan pengetahuan lingkungan hidup siswa SMK Kemenperin yang bagus belum mampu membentuk sikap peduli lingkungan yang bagus pula, contohnya pengetahuan siswa tentang pencegahan dan kerusakan lingkungan tinggi tetapi rendah dalam sikap menanam pohon dan merawat tanaman. Pengetahuan siswa menngenai pengelolaan dan $5 \mathrm{R}$ (reduce, reuse, recycle, replace dan replant) tinggi tapi sikap dalam menggunakan produk ramah lingkungan masih rendah.

Hasil pengamatan peneliti pengetahuan lingkungan hidup belum mampu membentuk sikap peduli lingkungan tercermin dari kesadaran siswa terhadap kebersihan ruang kelas dan lingkungan sekolah yang masih rendah. Masih belum memiliki kesadaran untuk mengambil sampah yang ada disekitar lingkungan, masih harus diingatkan oleh guru. Hal ini juga menunjukkan pemahaman siswa tentang pengetahuan lingkungan hidup masih dalam tingkatan rendah, hanya mampu tahu dan memahami belum sampai pada tingkatan pengetahuan yang lebih tinggi yaitu sintesis dan evaluasi..

Hasil penelitian ini sesuai dengan penelitian Lendrawati (2013) menyatakan bahwa pengetahuan peserta didik terhadap lingkungan tergolong tinggi, belum menjamin kepedulian peserta didik terhadap lingkungan juga tinggi. Menurut Meyer (2015) tidak selalu tingkat pengetahuan yang tinggi akan mendorong seseorang untuk berperilaku peduli lingkungan.

\section{Analisis hubungan antara Sikap Peduli Lingkungan terhadap Intensi Perilaku Peduli Lingkungan.}

Hasil analisis menggunakan SmartPLS 2 menunjukkan hubungan antara Sikap Peduli Lingkungan dengan Intensi perilaku peduli lingkungan sebesar 0.356, dengan nilai t hitung $3.28>1.988$ seperti dalam Tabel 6, yang berarti sikap peduli lingkungan berpengaruh nyata terhadap intensi perilaku peduli lingkungan. Semakin tinggi sikap peduli lingkungan, maka semakin tinggi pula intensi perilaku peduli lingkungan, contoh sikap siswa SMK Kemenperin yang sangat 
baik terhadap kepedulian membuang sampah, maka semakin tinggi pula intensi perilaku siswa SMK Kemenperin dalam membuang sampah pada tempat dan sesuai kriteria.

Temuan ini sejalan dengan asumsi teoritis dalam teori perilaku berencana (Ajzen, 1991) bahwa sikap merupakan faktor determinan dari intensi. Suki (2013) yang menemukan bahwa sikap lingkungan berpengaruh positif dan signifikan terhadap perilaku ekologis.

Hasil yang sama juga dilaporkan oleh Kumar (2014) yang meneliti perilaku membeli produk ramah lingkungan menyatakan bahwa sikap memiliki hubungan yang signifikan dengan niat untuk membeli produk yang ramah lingkungan. .Hasil penelitian ini juga sesuai dengan hasil penelitian Gusti (2015) yang meneliti hubungan pengetahuan, sikap dan intensi perilaku pengelolaan sampah berkelanjutan pada siswa sekolah dasar di Kota Padang. Hasilnya menyatakan bahwa sikap terhadap pengelolaan sampah berkelanjutan berhubungan dan berkontribusi positif dengan intensi pengelolaan sampah berkelanjutan.

Menurut teori Planned Behavior (Ajzen, 2005), sikap secara langsung mempengaruhi intensi perilaku. Keinginan seseorang untuk melakukan sesuatu dipengaruhi apakah seseorang memiliki penilaian positif (bermanfaat, penting, menyenangkan, mudah, dan sebagainya) atau memiliki penilaian negatif (mengganggu, tidak penting, buruk, dan sebagainya). Pengaruh sikap terhadap intensi perilaku peduli lingkungan siswa dapat dilihat dari pandangan siswa mengenai manfaat, keuntungan dan kepercayaan terkait kepedulian lingkungan.

\section{Analisis hubungan antara Norma Subjektif terhadap Intensi Perilaku Peduli Lingkungan.}

Hasil analisis menggunakan SmartPLS 2 menunjukkan hubungan antara norma subjektif dengan Intensi perilaku peduli lingkungan sebesar 0.236, dengan nilai t hitung $2.02>1.988$ seperti dalam Tabel 6, yang berarti norma subjektif berpengaruh nyata terhadap intensi perilaku peduli lingkungan. Semakin tinggi norma subjektif siswa SMK Kemenperin, maka semakin tinggi pula intensi perilaku peduli lingkungan

Hasil penelitian ini sesuai hasil penelitian yang dilakukan oleh Suryandari et al, (2016) yang meneliti perilaku ekologis generasi Y di Kota Denpasar bahwa semakin tinggi norma subyektif, maka semakin tinggi pula perilaku ekologis pada kelompok generasi Y di Kota Denpasar. Hasil penelitian ini juga memperkuat hasil penelitian sebelumnya Jaolis (2011); dan 
Lee (2008), yang menunjukkan bahwa kelompok acuan dalam lingkungan sosialnya seperti keluarga, teman, teman belanja, selebriti, dan ahli mempengaruhi perilaku ekologis mereka dalam hal pembelian produk hijau.

Norma subyektif adalah kecenderungan siswa SMK Kemenperin untuk tunduk kepada pendapat orang tua yang digunakan sebagai referensi atau panutan dalam bertindak. Indikator dominan yang merefleksikan variabel ini adalah "saran untuk berperilaku peduli pada lingkungan.

\section{Analisis hubungan antara Persepsi Kontrol Perilaku terhadap Intensi Perilaku Peduli Lingkungan}

Hasil analisis smartPLS 2 hubungan variabel persepsi kontrol perilaku terhadap Intensi Perilaku Peduli Lingkungan sebesar 0.305, dengan nilai t hitung atau signifikansi $3.53>1.988$ seperti dalam Tabel 6, yang berarti persepsi kontrol perilaku berpengaruh nyata terhadap pembentukan intensi perilaku lingkungan. Hasil penelitian tersebut sesuai dengan penelitian Rezai et al, (2012) yang menyatakan bahwa persepsi kontrol perilaku mempengaruhi perilaku ekologis dalam hal pembelian dan konsumsi produk ramah lingkungan. Penelitian ini juga diperkuat penelitian sebelumnya, Barkatin (2016) yang mengatakan persepsi kontrol perilaku mempunyai louding faktor 0.28 terhadap intensi perilaku lingkungan. Hasil penelitian (Sari, 2009. dalam Barkatin, 2016) menyatakan bahwa persepsi berpengaruh terhadap perilaku hidup bersih dan sehat masyarakat.

Persepsi kontrol perilaku adalah persepsi individu mengenai mudah atau sulitnya mewujudkan suatu perilaku tertentu (Ajzen, 2005). Persepsi kontrol perilaku peduli lingkungan adalah persepsi siswa SMK Kemenperin mengenai mudah atau sulitnya mewujudkan suatu perilaku peduli lingkungan berdasarkan kepercayaan mengenai kemampuan dalam mengendalikan dan persepsi mengenai kekuasaan yang dimiliki untuk melakukan perilaku peduli lingkungan.. Persepsi kontrol perilaku dalam penelitian ini direfleksikan secara dominan oleh indikator yaitu "Memiliki taman dan tanaman di sekolah maupun di rumah".

\section{REFERENSI}

Afandi, R. 2013. Integrasi Pendidikan Lingkungan Hidup Melalui Pembelajaran IPS di Sekolah Dasar sebagai Alternatif Menciptakan Sekolah Hijau. Jurnal pedagogia, vol. 2(1), Februari 2013 halaman 98-108.

Ajzen, I. 1991. The Theory of Planned Behavior, Organizational Behavior and Human Decision Processes 50(2).

Ajzen, I. 2005. Attitudes, Personality, and Behavior (2nd. Edition). England: 
Open University Press. McGrawHill.

Barkatin. 2016. Analisis Perilaku Pelajar Terhadap Lingkungan (studi kasus: pendidikan menengah di Kecamatan Parung, Kecamatan Ciseeng dan Kecamatan Gunung Sindur Kabupaten Bogor. Tesis. PSL Pascasarjana. IPB. Bogor.

Dwiwahjono, A.S. 2019. 15 Pabrik Danone-Aqua raih penghargaan industri hijau. https://www. beritasatu.com/ekonomi/590925 /15-pabrik-danoneaqua-raihpenghargaan-industri-hijau Desember 2019).

Ghozali, I. 2011. Structural Equation Modelling Metode Alternatif dengan Partial Least Square, Badan Penerbit Undip, Semarang.

Gusti, A., Isyandi, I., Bahri, S., Afandi, D.2015. Hubungan Pengetahuan, Sikap dan Intensi Perilaku Pengelolaan Sampah Berkelanjutan pada Siswa Sekolah Dasar di Kota Padang. Journal Dinamika Lingkungan Indonesia, Juli 2015,p 100-107.

Jaolis, F. 2011. Profil Green Consumers Indonesia: Identifikasi Segmen dan Faktor-faktor yang Mempengaruhi Perilaku Pembelian Green Products. Jurnal Mitra Ekonomi dan Manajemen Bisnis, 2 (3): 18-39.

Kementerian Perindustrian. 2019. Daftar peraturan keputusan menteri perindustrian. $\quad \mathrm{http}: / / \mathrm{jdih}$. kemenperin.go.id/site/peraturan/ 18/all/ (26 Desember 2019).

Kumar, B. 2014. Theory of Planned Behaviour Approach to Understand the Purchasing Behaviour for Environmentally.

Kostova, Z. dan Atasoy, E. (2008). Methods of Successful Learning.
Environmental Education. Journal of Theory and Practice in Education, vol. 4(1), p48-78

Lee, K. 2008. Opportunities for Green Marketing : Young Consumers. Journal of Marketing Intelligence and Planning, 26 (6): 573-586..

Lendrawati. 2013. Faktor-faktor Determinan yang Berhubungan dengan Kepadulian Peserta Didik SMP Cendana Pekanbaru Terhadap Lingkungan Sekolah. Jurnal Pusat Penelitian Lingkungan Hidup.Riau (ID): Universitas Riau.

Meyer, A. 2015. Does Education Increase pro Environmental Behavior? Evidence from Europe. Jurnal Ecological Economic, 116,108121.

Rezai, G., Teng, P.K., Mohamed, Z., Shamsudin, M.N. 2012. Consumer's Awareness and Consumption Intention Towards Green foods. African Journal of Business Management, 6 (12): 44964503.

Sarwono, Narimawati. 2015. Membuat Skripsi, Tesis dan Disertasi dengan Partial Least Square SEM (PLS SEM). Andi. Yogyakarta

Suryandari, N.K.D., Suprapti, N.W.S., Sukaatmadja, $\quad$ I.P.G. 2016. Aplikassi Theory of Planned Behavior dalam Menjelaskan Perilaku Ekologis Generasi Y di Kota Denpasar. Jurnal Manajemen, Strategi Bisnis dan Kewirausahaan Vol. 10, No. 1, Februari 2016. Universitas Udayana. Bali. 